\title{
Large-scale and high-resolution 3-D cave mapping by terrestrial laser scanning: a case study of the Domica Cave, Slovakia
}

\author{
Michal Gallay ${ }^{*}$, Ján Kaňuk ${ }^{1}$, Zdenko Hochmuth ${ }^{1}$, John D. Meneely², Jaroslav Hofierka ${ }^{1}$, \\ and Vladimír Sedlák ${ }^{1}$
}

${ }^{1}$ Institute of Geography, Faculty of Science, Pavol Jozef Šafárik University in Košice, Jesenná 5, 04001 Košice, Slovak Republic

${ }^{2}$ School of Geography, Archaeology and Palaeoecology, Queen's University Belfast, BT7 1NN Belfast, UK

\begin{abstract}
Mapping and modelling the complicated geometry of caves is a challenging task that has traditionally been undertaken by tacheometric surveying methods. These methods are excellent for capturing the general shape of a cave system but they are not suitable for high-speed, high-resolution mapping of complex surfaces found in this environment. Terrestrial laser scanning (TLS) technologies can acquire millions of points represented by 3 -D coordinates, at very high spatial densities on complex multifaceted surfaces within minutes. In the last few years, advances in measurement speed, reduction in size / cost and increased portability of this technology has revolutionised the collection of 3-D data. This paper discusses the methodological framework and the advantages / disadvantages of adopting terrestrial laser scanning to rapidly map a complex cave system on the example of the Domica Cave in Slovakia. This cave originated in the largest karst region in the West Carpathians. The collected data set or 'point cloud' contains over 11.9 billion of measured points, captured in 5 days from 327 individual scanning positions. The dataset represents almost $1,600 \mathrm{~m}$ of the cave passages. Semi-automatic registration of these scans was carried out using reference spheres placed in each scene and this method archived an overall registration error of $2.24 \mathrm{~mm}$ (RMSE). Transformation of the final registered point cloud from its local coordinate system to the national cartographic system was achieved with total accuracy of $21 \mathrm{~mm}$ (RMSE). This very detailed data set was used to create a 3-D cave surface model needed for volumetric analyses. In the future, it will be used for spatial analyses or simulating the interaction of surface and subsurface processes contributing to the development of the cave system on the basis of a 3-D GIS platform.
\end{abstract}

Keywords: fieldwork; cartography; instruments; history; survey

Received 18 Mar 2015; Revised 16 Jul 2015; Accepted 22 Jul 2015

Citation: Gallay M., Kaňuk J., Hochmuth Z., Meneely J.D., Hofierka J. and Sedlák V., 2015. Largescale and high-resolution 3-D cave mapping by terrestrial laser scanning: a case study of the Domica Cave, Slovakia. International Journal of Speleology, 44 (3), 277-291. Tampa, FL (USA) ISSN 0392-6672 http://dx.doi.org/10.5038/1827-806X.44.3.6

\section{INTRODUCTION}

Mapping and modelling the complex geometry of caves is traditionally a challenging task. Limited accessibility and light conditions make mapping of cave morphology very difficult. Traditional tacheometric methods are based on mine surveying (Hochmuth, 1995; Ganter, 2000). This is a labour intensive and time-consuming work often conducted under high-risk conditions (Buchroithner, 2015). The equipment used comprises accurate mining suspension compass with clinometer, appropriate theodolites, or total stations. Other, faster methods exploit indirect mapping based on electromagnetic tomography (Pánek et al., 2010; Kasprzak et al., 2015), ground penetrating radar, or gravity (Chamberlain et al., 2000; Beres et al., 2001). These methods are useful to detect underground hollow spaces but they provide limited information about spatial details with low levels of accuracy. Image-based photogrammetric surveying can also be used in cave studies but the difficulty of achieving homogeneous light conditions is a limiting factor (Grussenmeyer et al., 2012; Remondino et al., 2014).

Recent developments in terrestrial laser scanning (TLS) technology (Mallet \& Bretar, 2009; Vosselman \& Maas, 2010; Höfle \& Rutzinger, 2011; Bosse et al., 2012; Bremer \& Sass, 2012; Buckley et al., 2013; McFarlane et al., 2015) provide new approaches to mapping the complex environment of caves. The archaeological survey in the Wemyss Caves in 
Scotland (The Courier, 2004) is considered to be one of the first applications of TLS in caves. Since then, the TLS has been used intensively especially for heritage documentation (Patias et al., 2008). Buchroithner (2015) reports the history of cave laser scanning in more detail. Terrestrial laser scanners acquire millions of $\mathrm{x}, \mathrm{y}, \mathrm{z}$ measurements in a single scan resulting in a three-dimensional (3-D) point cloud within minutes. As a remote sensing method, this technology allows for mapping distant parts of caves inaccessible to a surveyor providing a direct line of sight between the scanner and the surface. TLS reduces the amount of time and physical effort involved in cave mapping while providing a high level of detail and measurement accuracy. This emphasizes an interesting aspect of cave research which is in exploiting a detailed cave representation in a digital form for the measurement, modelling and morphometric analysis and its integration with other geospatial data.

TLS has been used in previous studies to obtain accurate three dimensional models of caves. These studies were motivated by the need for improved cartographic visualisation and geomorphological analysis (Buchroithner et al., 2011; Canevese et al., 2011; Roncat et al., 2011; Silvestre et al., 2015). TLS has been used in ice caves to measure the ice surface (Gašinec et al., 2012; Milius \& Petters, 2012) Others have used TLS for archaeological (Birch, 2008; Gonzalez-Aguilera et al., 2009; Burens et al., 2014) and zoological research (Azmy et al., 2012; McFarlane et al., 2015), for heritage management and tourism (Schön, 2007; Buchroithner \& Gaisecker, 2009; Rüther et al., 2009; Addison, 2011; Gede et al., 2013; Zlot \& Bosse, 2014; Marsico et al., 2015). TLS data have been combined with other spatial data, for example, cave photography (Lerma et al., 2009), orthothermography (Berenguer-Sempere et al., 2014) or data from the surface above the cave (McFarlane et al., 2013; Hoffmeister et al., 2014). Fly-through animations based on 3-D cave models also provide new means for improved perception of the cave systems (YouTube, 2013; National Geographic, 2014).

However, we can still identify two main challenges in using TLS for cave modelling. The first is in processing such large data sets produced by this method and generating 3-D surfaces from them (Roncat et al., 2011; Silvestre et al., 2013; Cosso et al., 2014; Hoffmeister et al., 2014) and integrating this volume of data with other spatial datasets, for example in a geographic information system (GIS).

The second challenge is accessibility, physically moving the equipment around this harsh environment with narrow passages, low ceilings, high humidity, mud and water, etc. Therefore, TLS is not a universal method for mapping complex cave environments and it cannot totally replace more traditional techniques especially in extreme conditions. An overview of selected case studies involving the use of TLS in cave mapping, including time spent, distance covered and the number of points collected is shown in Table 1.

In this paper, we review terrestrial laser scanning technology applied in cave mapping and we present our methodology adopted in acquiring a highly detailed and accurate digital representation of a large-scale cave system. This study aims to formulate main steps, technical details, and related problems to achieve efficient terrestrial laser scanning of a cave in order to capture its fine-scale representation. We describe main tasks and operations needed for creation of a 3-D cave surface model from the TLS data. The 3-D model is used to parameterize volumetric properties of the cave with the aim of analysing cave morphology. The methodology is applied in the Domica Cave in Slovakia, which is a part of Domica-Baradla, one of the largest cave systems in the West Carpathians.

\section{THE TERRESTRIAL LASER SCANNING APPROACH}

\section{Traditional cave mapping and TLS}

The mapping of caves is traditionally a difficult task due to the harsh underground conditions includinglack of light, flowing water, high humidity, limited space, and complex morphology. Often, the remoteness of cave entrance makes the transport of heavy surveying equipment very demanding. Hence, cave mapping has usually relied on tacheometric surveying with light weight instruments such as a mining compass and clinometer. Total station has sometimes been preferred in caves with an easier access and walking conditions. Both methods are suitable for capturing the general shape of a cave system. However, they are not suitable for high-resolution mapping as they provide only a limited number of points to represent the cave surfaces. Conventional cave maps are created using simple measurements of angles and distances, traditionally showing a planimetric view of the cave with a limited number of cross-sections to represent the 3-D nature of the cave. This kind of data can be integrated and used for approximate 3-D modelling (Budaj \& Mudrák, 2008; Heeb, 2009), but its accuracy is subject to the expertise of the surveying teams. Also this traditional approach does not capture the morphology of cave walls and ceilings which are difficult to be surveyed while they often bear important information on the formation of the cave. For example, the ceiling morphology could provide evidence about flowing water or small morphological forms such as solutional sculptures (e.g. scallops), linear landforms related to tectonics or ceiling channels as the evidence of paragenetic evolution of the cave. Such forms are usually photographed, but their accurate mapping is difficult due to problematic accessibility.

Many of these limitations in traditional cave mapping can be addressed by using TLS. 3-D laser scanners are active remote sensing systems enabling high-resolution measurements of point coordinates on surfaces depending on the distance between the mapped surface and the instrument resulting in a huge amount of 3-D points representing the surfaces. The large data sets captured by TLS are called 'point clouds'. They contain the $\mathrm{x}, \mathrm{y}, \mathrm{z}$ coordinates for each point and also an intensity value (i) of the reflected laser beam. It is also possible to colorize the points for further rendering by assigning the three RGB values as additional attributes to the point positions. The RGB 
values are sampled from $360^{\circ}$ photographic imagery recorded by a camera integrated in the scanner or by taking photographs with a camera independent of the scanner. In the latter case, the photoimagery is co-registered with the point cloud in the postprocessing stage (Milius \& Petters, 2012). However, sufficient light conditions have to be ensured for recording suitable photography to overtake the cave darkness. There are currently solutions, such as highperformance LED lamps, to illuminate underground spaces and get images for texturing. If possible, an ambient light should be preferred as this light setup limits occurrence of possible shadows on the area.

There are a number of terrestrial laser scanners and an overview of five most commonly used systems in cave mapping, their physical size, weight, range, accuracy, etc. is given in Table 1. Lemmens (2007) provides a more detailed overview of earlier scanners. The devices in Table 1 differ in functioning principles, inbound signal reception, and processing systems. Their maximum range varies from tens of metres up to a kilometre. The scanned ranges in caves typically reach several tens of metres therefore long-range scanners do not provide much of benefit in caves. Minimum range is also an important parameter when considering a TLS scanner suitable for use in caves, as short minimal range can be an advantage when working in narrow spaces. Other technical specifications such as accuracy, field of view, range, measurement speed, pulse wavelength, weight, dimensions, toughness, power supply, user interface, data storage and transfer, peak operating temperature and humidity levels, should all be taken into account when choosing a system for underground mapping.

\section{From individual scans to a single point cloud}

A digital representation of the entire cave is generated by accurately combining individual point clouds acquired from several scanning positions so that they are correctly oriented within a common local coordinate system (Lichti \& Skaloud, 2009). The positional registration of individual scans is achieved via the identification and matching of common points between two scans. At least three such points must be identified for correct alignment in all three dimensions. Several approaches can be used for doing this. Different scans which overlap each other can be aligned based on identical points which are manually identified in each point cloud. In complex scenes such as caves, this method can be very timeconsuming but the operator has full-control over the scans alignment. The study of Lindgren \& Galeazzi (2013) argues why manual alignment was preferred in their case. In general, it is more efficient to use reference targets placed within the scanner's field of view. The targets may be planar or geometric primitives for example black-and-white checker boards or spheres. Registration software, usually supplied with a scanning system, can recognize these targets and align the scans automatically or semi-automatically. The advantage of a spherical target is that, in theory, 50 percent of the sphere surface can be seen from the instrument location. The set of points sampled on the sphere surface is used to model a complete sphere and then calculate its centre which is then used as a registration point. More details on theory of scan registration can be found in Lichti \& Skaloud (2009) and the issue of TLS is thoroughly addressed, for example, in Vosselman \& Maas (2010).

The morphology of natural caves is usually complex and much more diverse than a man-made tunnel or a mine corridor. This complexity increases the number of scanning positions needed in order to fully capture the cave surface and reduce blind spots - areas where no data are collected. Overcoming this problem requires proper planning and thinking ahead for scanning locations, including the placement of the reference targets. To increase the positional accuracy of the registration process, the targets should be placed at different heights and not along a straight line.

The ultimate goal of laser scanning a cave is the acquisition of a georeferenced point cloud.

Table 1. Technical parameters of selected terrestrial laser scanners used for cave mapping

\begin{tabular}{|c|c|c|c|c|c|}
\hline Laser scanner model & $\begin{array}{l}\text { FARO FOCUS } \\
\text { 3D S } 120\end{array}$ & $\begin{array}{c}\text { LEICA } \\
\text { ScanStation C10 }\end{array}$ & $\begin{array}{c}\text { LEICA } \\
\text { HDS6100 }\end{array}$ & $\begin{array}{l}\text { RIEGL LMS- } \\
\text { Z420i }\end{array}$ & Zebedee \\
\hline Range & $0.6-120 \mathrm{~m}$ & $1.5-300 \mathrm{~m}$ & $1 \mathrm{~m}-79 \mathrm{~m}$ & $2 \mathrm{~m}-1,000 \mathrm{~m}$ & $35 \mathrm{~m}$ \\
\hline $\begin{array}{l}\text { Maximum measurement } \\
\text { rate (points per second) }\end{array}$ & 976,000 & 50,000 & 500,000 & $8,000-11,000$ & 43,200 \\
\hline Accuracy & $\pm 2 \mathrm{~mm}$ at $10 \mathrm{~m}$ & $\pm 6 \mathrm{~mm}$ at $50 \mathrm{~m}$ & $\begin{array}{c} \pm 1 \mathrm{~mm} \text { at } 25 \mathrm{~m} \\
\pm 2.4 \mathrm{~mm} \text { at } 50 \mathrm{~m}\end{array}$ & $\pm 10 \mathrm{~mm}$ at $50 \mathrm{~m}$ & $\pm 10-30 \mathrm{~mm}$ \\
\hline Wavelength & $1,550 \mathrm{~nm}$ & $532 \mathrm{~nm}$ & $650-690 \mathrm{~nm}$ & $1,550 \mathrm{~nm}$ & $905 \mathrm{~nm}$ \\
\hline Horizontal field of view & $360^{\circ}$ & $360^{\circ}$ & $360^{\circ}$ & $360^{\circ}$ & $360^{\circ}$ \\
\hline Vertical field of view & $300^{\circ}$ & $270^{\circ}$ & $310^{\circ}$ & $80^{\circ}$ & $270^{\circ}$ \\
\hline Weight without batteries & $5.2 \mathrm{~kg}$ & $13 \mathrm{~kg}$ & $14 \mathrm{~kg}$ & $16 \mathrm{~kg}$ & $0.430 \mathrm{~kg}$ \\
\hline $\begin{array}{l}\text { Dimensions } \\
(\mathrm{LxWxH})\end{array}$ & $240 \times 200 \times 100 \mathrm{~mm}$ & $238 \times 358 \times 39 \mathrm{~mm}$ & $244 \times 190 \times 351.5 \mathrm{~mm}$ & $463 \times 210 \mathrm{~mm}$ & $60 \times 60 \times 85 \mathrm{~mm}$ \\
\hline Application study & $\begin{array}{c}\text { McFarlane et al. } \\
\text { (2013), } \\
\text { Lindgren and } \\
\text { Galeazzi (2013), } \\
\text { Gede et al. (2013) }\end{array}$ & $\begin{array}{c}\text { Berenguer- } \\
\text { Sempere et al. } \\
\text { (2014), Gašinec et } \\
\text { al. (2012), } \\
\text { Gede et al. (2013) }\end{array}$ & $\begin{array}{l}\text { Canevese et al. } \\
\text { (2011) }\end{array}$ & $\begin{array}{c}\text { Buchroithner \& } \\
\text { Gaisecker (2009), } \\
\text { Hoffmeister et al. } \\
\text { (2014) }\end{array}$ & $\begin{array}{c}\text { Zlot \& Bosse } \\
\text { (2014), } \\
\text { Bosse et al. } \\
(2012)\end{array}$ \\
\hline
\end{tabular}


Georeferencing involves transformation of the final registered data set from its own local coordinate system to a global or national cartographic system. Such a dataset can also be integrated with other georeferenced spatial data in a GIS and usually it is used for generating a 3-D cave surface. There are several approaches that can be used for georeferencing TLS data. Each position of the scanner and/or the position of signalised markers (survey nails, reference targets) can be measured and connected to an existing national geodetic network via tacheometric traversing. Buchroithner \& Gaisecker (2009) used this approach when TLS mapping a cave in an alpine environment. They measured marked ground-control points by a measuring tape and analogue theodolite during previous campaigns to obtain the correct orientation of the point-cloud acquired by the scanner, within the geographic coordinates. A similar methodology was applied by Gašinec et al. (2012) or Bella et al. (2015). Another approach to georeferencing is to measure geodetic coordinates of at least three noncollinear signalised markers outside the cave system using global navigation satellite systems (GNSS). This approach saves time, as no traverse surveying in the cave is required but it does require an accurately registered TLS survey. Surveying of these points in a cartographic system can also be done at a later date. Table 1 includes the method for registration and georeferencing on a number of selected case studies involving the use of TLS in cave mapping. This comparison shows that TLS is usually realised for relatively small caves or shorter parts of caves in the order of tens or rarely few hundreds of metres for which only several scanning positions are necessary. Hence, the actual survey takes only a few hours in total. The time required for TLS increases with the length of the surveyed cave, more specifically, with the number of scanning positions. Zlot \& Bosse (2014) present a promising technique in which they applied a mobile laser scanning approach to cave mapping where a single operator carries a lightweight, handheld 3-D laser scanner. The survey is an outstanding example of high-resolution mapping of $17 \mathrm{~km}$ of cave corridors within less than 16 hours. However, the accuracy of matching identical points scanned from the walked trajectory is not as high as if the cave system is scanned from static positions of a scanner. The standard deviation of errors relative to reference data for different environments and short tracks is between 20 - $50 \mathrm{~mm}$ (Bosse et al., 2012). While the application of this mobile scanning technique is very flexible and time-efficient the accuracy depends largely on cave geometry and on the operator's traverse length. The propagation of errors reaches the order of metres in open traverses (Zlot \& Bosse, 2014). Lindgren \& Galeazzi (2013) or Canevese et al. (2011) acquired a comparable number of points but within much longer duration of several days to weeks, respectively. The trade-off was in achieving much better accuracy of scan alignment with scanning from static positions as opposed to the onthe-fly registration of mobile scanning data.

\section{3-D cave representations}

The final georeferenced point cloud per se can be used as the ultimate tool for extracting new information about the cave system by means of interactive visualization, measurement of distances, creation of cross-sections, or dynamic visualization (animations). However, spatial analyses and modelling the phenomena related to surface morphology requires generation of a 3-D digital surface model. Continuous 3-D cave model which is textured and coloured is also much more appealing for visualization and animation purposes. While working with the point cloud is relatively easy, creation of the 3-D surface model is an additional step in production of high-resolution cave representations which requires additional software tools and computer resources needed to process a huge dataset of the point cloud. The main idea is to create a polygonal mesh by connecting individual points. The point cloud has to be usually decimated before meshing to reduce the computational demands but the level of detail is still high. The 3-D model enables analysis of the cave surface and its volumetric properties. Integration of a high-resolution cave model in a GIS opens possibilities of using wide range of tools for analysing the surface and relations with landscape above the cave. However, analysis of high-resolution 3-D models in a GIS still remains a challenge. For example, McFarlane et al. (2015) treated the cave ceiling as a 2-D digital terrain model to which they applied a classification procedure to identify bats and their nests. Currently, 3-D cave surfaces from laser scanning data need to be generated using other kinds of software. For more details on methodologies for this issue, the reader is advised to consult works by Roncat et al. (2011), Cosso et al. (2014), Hoffmeister et al. (2014), Buchroithner (2015), or Silvestre et al. (2015) which exploited commercial software or opensource software for $3-D$ cave surface modelling.

\section{STUDY AREA}

The study area is located at the south-western edge of the Slovak Karst area near the state border of Slovakia with Hungary (48²8'40.4”N, 20²8'12.9”E) (Fig. 1). The total length of the cave system is around $5,400 \mathrm{~m}$, however, it does continue into the Aggtelek karst region in Hungary as the Baradla with a combined length of 26,065 m (CAVERBOB). Average annual air temperature varies between 10 and $11^{\circ} \mathrm{C}$ and air humidity is between 95 and 98\%. The Domica Cave was formed by corrosive-erosive processes caused by surface fluvial water and temporary streams which sank underground at the contact of the Middle Triassic white limestones and the Pontian fluviallacustrine gravel-sand-clay sediments. The tectonic framework was generated by south to southeast oriented pressures which caused stress, and the compression was realised in the range of directions of north-south to northwest-southeast (Gaál \& Vlček, 2011). The oldest (upper) parts of the Domica cave (341 m a.s.1.) began to form after the uplift of the region above sea level in the Upper Pliocene (Bella et al., 2014) when the current hydrographic network 
was being established. The cave is a result of the underground flow of the Styx and Domický potok rivers shown by the oval shapes of the corridors and the quantity of allochthonous pebbles found in the system. The lowest level was found by drilling into the current river bed of Styx at $318 \mathrm{~m}$ a.s.1. below $16 \mathrm{~m}$ thick layer of sediments (Droppa, 1972).

The cave is noteworthy for several reasons. It is one of the richest archaeological sites of the Neolithic Bükk culture 65007300 BC (Bárta, 1965; Lichardus, 1968; Gradziński et al., 2007). After a natural blockage of the cave entrance in this period, the cave remained hidden until Ján Majko rediscovered it in 1926. It then became legally protected, minimizing the impact of unmanaged human interference. The show cave opened to visitors in 1932 . This section is over $930 \mathrm{~m}$ long and in some parts visitors can take short boat trips. The cave has specific environmental conditions to which new biological findings are related (Nováková, 2009; Kováč \& Rusek, 2012; Papáč et al., 2014; Svitavská-Svobodová et al., 2015). The cave was subject to measurement of radon air concentration by Mihailović et al. (2015).

There are several reasons for choosing this particular site to study. The landscape surrounding the Domica Cave is one in which superficial and underground processes strongly interact. For example, in the recent history, several rainfall events caused major flooding in the cave also worsened by inappropriate agricultural practise (Bella, 2001; Gaalova et al., 2014). Integration of detailed 3-D superficial data and underground 3-D data will allow a detailed morphometric analysis of the karst system and digital modelling of processes forming the landscape to be carried out. Furthermore, this cave is the beginning of a much larger crossborder underground system; therefore, the influence of the Domica Cave area to the formation of the other parts of the system can be assumed. Moreover, the cave is a listed UNESCO Natural World Heritage site and a detailed 3-D model derived from laser scanning can help in site management and act as a catalyst for further research and educational initiatives.

\section{METHODOLOGICAL APPROACH}

Our workflow of mapping the Domica Cave consisted in four major phases: (i) collection of existing data and preliminary mapping, (ii) laser scanning phase, (iii) data post-processing, georeferencing, and (iv) visualization.

\section{Collection of existing data and preliminary mapping}

This phase involved assembling all available documents on the cave, especially maps, published reports and survey records. All caves in the Slovak

$16^{\circ} \mathrm{E} \quad 18^{\circ} \mathrm{E} \quad 20^{\circ} \mathrm{E} \quad 22^{\circ} \mathrm{E} \quad 24^{\circ} \mathrm{E} \quad 26^{\circ} \mathrm{E}$
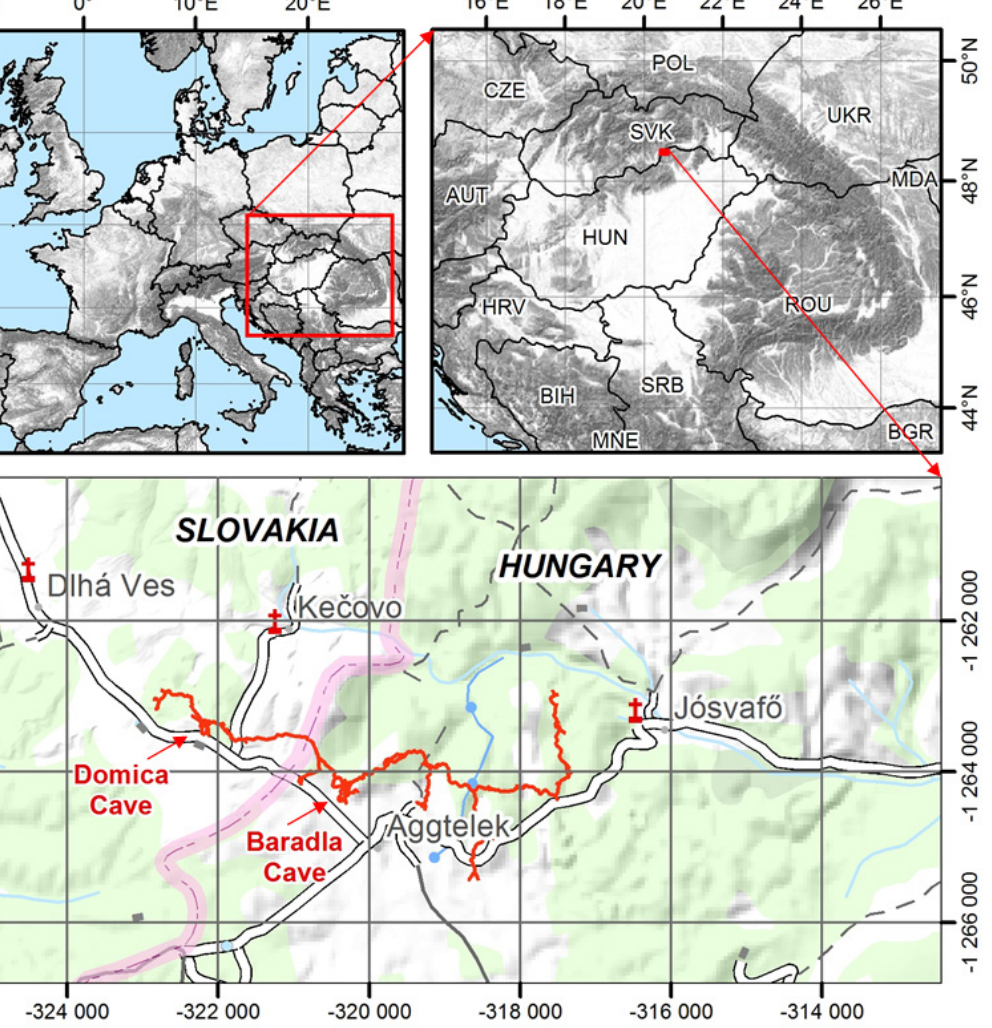
Droppa (1972) and Kessler (1938). The red arrows indicate cave entrances. The cartographic coordinates of the bottom map are in the Slovak national grid system in metres (SJTSK, EPSG code 5514).

Republic are legally protected by the Fifth (highest) level of nature protection. For that reason, permission of the Slovak Cave Administration had to be granted prior to any activity. Cave reconnaissance is an inevitable and necessary step for identification of the local environmental conditions and accessibility. This is especially important in case of an unknown cave for which no maps or other data exist.

Mapping of the cave was first undertaken by the mine surveyor Eduard Paloncy in the early 1930s (Paloncy, 1932). He used an optical theodolite and many of his reference points used to traverse this network can still be found. Kettner and Roth then surveyed some smaller areas (Kunský, 1950) until the cave was mapped in detail during 1950s and 1960s by Droppa and Chovan (Droppa, 1972). They used a mining compass with a clinometer and took advantage of the existing network of control points placed by Paloncy. The Droppa map records the full extent of the known Domica system in the scale of $1: 1,000$ including the cave of Certova diera. This map also includes vertical profiles of the Domica cave system. Then in 1975 the mine surveyors (Geological Survey, 1975; Novoveský, 1975) mapped the show cave and some previously unmapped passages which resulted in a planimetric map published at a scale of 1:500 (Fig. 2). This was the most accurate survey prior to our TLS mission. However, no profiles or cross-sections were constructed from this survey. The preserved report from the survey (Novoveský, 1975) states that an optical theodolite using a three-pedestal set was used for surveying seven traverses for a total of 117 stabilised points in the show cave. Inside the 


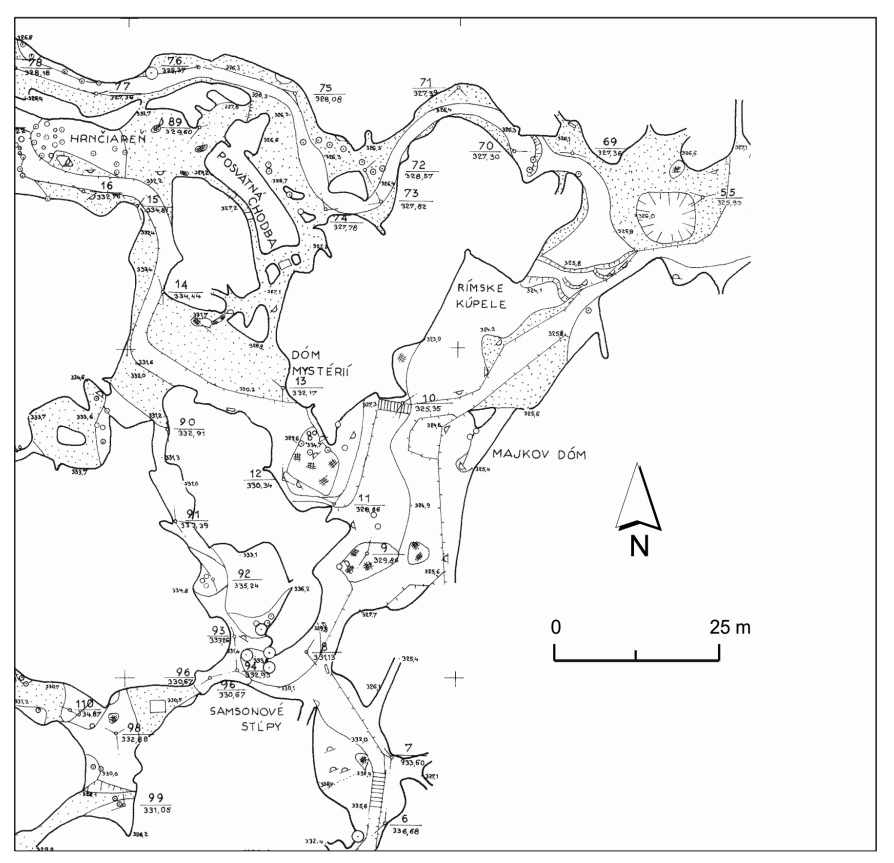

Fig. 2. Detail of the most recent map of the Domica Cave based on traditional tacheometric surveying by Geological Survey (1975) showing a part of the show cave. The extent of the map section is located in Fig. 3b.

cave, two traverses within the network were surveyed as closed loops. Three traverses were connected by two end points with other traverses in the network as compound traverses. Two traverses were measured as open with respect to the cave surveying network. The positional accuracy of the closed traverses was $16 \mathrm{~mm}$ and $41 \mathrm{~mm}$, respectively. The positional accuracy of compound traverses ranged between 30 to $130 \mathrm{~mm}$. The seven traverses were connected to the national grid network. The altitude was measured with respect to the Baltic Datum after adjustment (i.e., B.p.v) by technical or trigonometric levelling with accuracies ranging from 1 to $18 \mathrm{~mm}$. We have located 19 of these points in the cave suitable for the analysis of the registration and georeferencing errors and their propagation with respect to the stabilised network of the survey from 1975. The points are still well marked with an identification number and a nail which makes it easier to find in the TLS point clouds. The maps produced later on were related to the construction of some new artificial corridors and connecting corridors for a new entrance to the show cave (e.g., Bella \& Holúbek, 2001). The maps of Droppa (1972) and Geological Survey (1975) provided a basis for planning this laser scanning survey.

\section{Laser scanning phase}

The aim of this TLS survey was to capture a highresolution georeferenced point cloud of the Domica cave system which would depict small morphological features in the order of few millimetres. The dataset will be integrated with airborne laser scanning data and other spatial datasets within a GIS platform to enable multi-scale 3-D modelling of karst landscape and related phenomena (e.g., water flow, air temperature) by the means of 3-D GIS. For further details see the website of the SPATIAL3D project (http://spatial3d. science.upjs.sk/). The overriding constraint for this research was time, as it was restricted to only 5 days of surveying. This was a limiting factor from the point of view of the registration accuracy of the scans in the final point cloud. Therefore the survey was limited to the show cave and several adjacent publicly inaccessible corridors and it was decided not to make a simultaneous tacheometric surveying of the traverse, as this would have lead to considerable logistical difficulties. However, we could make use of the existing stabilised traverse from the geological survey in 1975 for error estimation. Considering these constraints, we conducted the TLS with a FARO Focus 3D S120 scanner mounted on a GITZO carbon fibre tripod with a panoramic head. This unit comprises an inbuilt electronic compass, barometer and inclinometer, which speed up the process of orienting the scans. Its relatively low weight $(5 \mathrm{~kg})$ and compact size, makes this scanner easily portable and it can be used in extremely narrow spaces where larger systems requiring a traditional survey tripod cannot be installed (Table 2). Laser ranging with the scanner is based on measuring the phase shift between the continuously emitted laser energy and the backscattered energy intercepted by the scanner. This technology enables higher frequency of measurement and higher precision in comparison with pulse-based scanners, although with the trade-off of relatively shorter maximum ranges.

The TLS commenced outside the cave to capture the structure of the Visitors Centre / Entrance (Fig. 3). Scanning the outdoor environment provides better perception of the final point cloud in relation to land surface and it was necessary to capture three rectangular checkerboard targets to be further used in georeferencing procedure. The checkerboards were surveyed in the area of the cave entrance using a dual frequency GNSS receiver Topcon Hyper II receiver with a mobile broadband connection to the Slovak Permanent Observation Service (SKPOS). The service broadcasts real time corrections for differential positioning. The imaging capacities of the FARO Focus scanner were used only for recording the cave visitor centre and surrounding area. We did not have sufficient equipment to improve the light conditions inside the cave; therefore, the option to collect imagery was turned off which also saved time and data storage for more scanning.

In order to achieve high accuracy and rapid progress through the cave system $145 \mathrm{~mm}$ diameter plastic spherical targets were used as reference targets for scan registration purposes. The basic requirement for the mutual alignment of two overlapping scans with spherical targets is that there are at least three spheres captured in both scans. The accuracy of the registration increases with increasing number of identical targets and allows for redundancy should one of the targets be disturbed. For over $70 \%$ of the scanning positions four common spheres were used and only two were moved to a new location between consecutive scans. In specific cases, such as scanning a short-range diversion from the main traverse, five and sometimes six spheres remained unmoved. Three were moved in cases where the morphological configuration of the 
Table 2. Overview of selected published case studies of cave mapping by terrestrial laser scanning.

\begin{tabular}{|c|c|c|c|c|c|}
\hline $\begin{array}{l}\text { Published } \\
\text { research }\end{array}$ & $\begin{array}{c}\text { Country of the } \\
\text { study }\end{array}$ & $\begin{array}{l}\text { Method of } \\
\text { alignment of } \\
\text { scans and their } \\
\text { georeferencing. }\end{array}$ & $\begin{array}{c}\text { Duration of } \\
\text { scanning }\end{array}$ & $\begin{array}{c}\text { Maximum } \\
\text { extension of the } \\
\text { space scanned }\end{array}$ & $\begin{array}{c}\text { Number of points } \\
\text { / scans }\end{array}$ \\
\hline $\begin{array}{l}\text { Canevese et al. } \\
(2009)\end{array}$ & Mexico & Unspecified & 3 hours & $110 \mathrm{~m}$ & $\begin{array}{l}43 \text { million / } 4 \\
\text { scans }\end{array}$ \\
\hline $\begin{array}{l}\text { Buchroithner \& } \\
\text { Gaisecker (2009) }\end{array}$ & Austria & $\begin{array}{c}\text { Target resection } \\
\text { and points surveyed } \\
\text { in a traverse } \\
\text { measured by a tape } \\
\text { and theodolite in } \\
\text { previous campaigns }\end{array}$ & $\begin{array}{l}10 \text { days including } \\
\text { transport of } \\
\text { equipment }\end{array}$ & ca. $100 \mathrm{~m}$ & $\begin{array}{l}\text { Unspecified / } 15 \\
\text { scans }\end{array}$ \\
\hline $\begin{array}{l}\text { Roncat et al. } \\
\text { (2011) }\end{array}$ & Austria & $\begin{array}{l}\text { Target resection and } \\
\text { manual selection of } \\
\text { identical points, no } \\
\text { georeferencing. }\end{array}$ & Within a day & $150 \mathrm{~m}$ & $\begin{array}{l}\text { 1,600 million / } 11 \\
\text { scans }\end{array}$ \\
\hline $\begin{array}{l}\text { Canevese et al. } \\
(2011)\end{array}$ & Italy & $\begin{array}{l}\text { Target resection and } \\
\text { points surveyed in } \\
\text { an open traverse } \\
\text { measured by a total } \\
\text { station. }\end{array}$ & 32 hours & $740 \mathrm{~m}$ & $\begin{array}{c}\text { 8,000 million / } 46 \\
\text { scans }\end{array}$ \\
\hline $\begin{array}{l}\text { Lindgren \& } \\
\text { Galeazzi (2013) }\end{array}$ & Belize & $\begin{array}{l}\text { Manual selection of } \\
\text { identical points and } \\
\text { GNSS positioning of } \\
\text { few control points. }\end{array}$ & $\begin{array}{c}3 \text { weeks including } \\
\text { other tasks }\end{array}$ & $\begin{array}{l}\text { Several hundreds } \\
\text { of metres }\end{array}$ & $\begin{array}{c}7,350 \text { million / } \\
350 \text { scans }\end{array}$ \\
\hline $\begin{array}{l}\text { Millius \& Petters } \\
(2012)\end{array}$ & Austria & $\begin{array}{l}\text { Target resection and } \\
\text { points surveyed in } \\
\text { an open traverse } \\
\text { measured by total } \\
\text { station. }\end{array}$ & Unspecified & ca. $1,000 \mathrm{~m}$ & $\begin{array}{c}6,500 \text { million / } \\
158 \text { scans }\end{array}$ \\
\hline $\begin{array}{l}\text { Zlot \& Bosse } \\
(2014)\end{array}$ & Australia & $\begin{array}{l}\text { On-the-fly, no } \\
\text { targets, GNSS } \\
\text { positioning of few } \\
\text { control points. }\end{array}$ & 15,5 hours & $17,100 \mathrm{~m}$ & $\begin{array}{l}2,700 \text { million / } \\
\text { unspecified }\end{array}$ \\
\hline $\begin{array}{l}\text { Burens et al. } \\
(2014)\end{array}$ & France & $\begin{array}{l}\text { Target resection and } \\
\text { points surveyed in } \\
\text { an open traverse } \\
\text { measured by a total } \\
\text { station. }\end{array}$ & 24 days & $430 \mathrm{~m}$ & $\begin{array}{l}\text { ca. } 4,300 \text { million } \\
\text { / over } 100 \text { scans }\end{array}$ \\
\hline $\begin{array}{l}\text { Berenguer- } \\
\text { Sempere et al. } \\
(2014)\end{array}$ & Spain & $\begin{array}{l}\text { Target resection and } \\
\text { points surveyed in } \\
\text { an open traverse } \\
\text { measured by total } \\
\text { station. }\end{array}$ & Within a day & $72 \mathrm{~m}$ & $\begin{array}{l}76 \text { million / } \\
\text { unspecified }\end{array}$ \\
\hline $\begin{array}{l}\text { Silvestre et al. } \\
(2015)\end{array}$ & Portugal & $\begin{array}{l}\text { Target resection } \\
\text { and points surveyed } \\
\text { in open traverse } \\
\text { measured by total } \\
\text { station. }\end{array}$ & Within a day & $80 \mathrm{~m}$ & $\begin{array}{l}45 \text { million / } 3 \\
\text { scans }\end{array}$ \\
\hline $\begin{array}{l}\text { McFarlane et al. } \\
(2015)\end{array}$ & Malaysia & $\begin{array}{l}\text { Target resection and } \\
\text { points surveyed in } \\
\text { traverse surveyed } \\
\text { by compass-based } \\
\text { techniques. }\end{array}$ & Unspecified & ca. $1,000 \mathrm{~m}$ & $\begin{array}{l}5,000 \text { million/ } \\
124 \text { scans }\end{array}$ \\
\hline
\end{tabular}


cave was too complex, e.g. winding corridors, narrow passages, or large speleothems causing blind spots. The location of the next scan and reference spheres was carefully considered for at least two or three scans ahead to minimize a movement of the spheres, which decreases the accuracy of registration, and to reduce data blind spots. This method produced a high accuracy of registration without any need for surveying the individual positions of each scan using a total station. The majority of individual scans were acquired within 6 or 9 minutes at a scanning resolution of $1 / 5$ or $1 / 4$ the maximum resolution of the scanner. This gave a point density of 7.6 or $6.1 \mathrm{~mm}$ at the range $10 \mathrm{~m}$ away from the scanner, respectively. In some instances the scanner was set to $1 / 2$ maximum resolution (point density $3 \mathrm{~mm}$ at $10 \mathrm{~m}$ range) especially in large caverns with high ceilings. In the case of looping cave corridors, additional checkerboard rectangular targets were placed within the scene at the start of these diversions and these targets remained there, undisturbed, until the continually traversing survey returned to this location where they were again laser scanned before being moved. If scanning was to continue the next day, the registration spheres were left undisturbed in the cave overnight. The entire TLS mission was accomplished between 3 and 7 March 2014, with 8-9 hours continuous scanning per day. The data collected that day were registered every evening using the FARO Scene software and then backed up.

\section{Data post-processing georeferencing}

and

The first step of data postprocessing involved relative registration of consecutive scans based on the reference spheres. This was carried out using FARO SCENE registration software. Although this software allows for fully automatic registration, a manual approach was used to continuously monitor the registration error between the consecutive scans. This phase of post-processing was carried out during the mission after each day of measurements and it took 3-4 hours using a standard laptop computer. After the survey was completed, an additional 10 hours in the office was needed for fine tuning the registration for all the 327 individual scans. The final step involved transformation of the complete registered point cloud from its local coordinates system to the Slovak national cartographic system (SJTSK, EPSG code 5514, http:// www.epsg-registry.org/) with the vertical reference to the Baltic Datum After Adjustment. For this task, the $\mathrm{x}$, $y, z$, positions and point ID's of the three checkerboard targets measured with a GNSS receiver were imported in FARO SCENE as a reference CSV text file. The checker board targets in the point cloud were given the same ID as the Slovak GNSS data. In addition, 3-D coordinates of a single point (GS108, Fig. 3) from the tacheometric survey undertaken in 1975 were used as the fourth point to reduce the georeferencing error propagation in the most distant part of the cave. Reregistering the four points transformed the point cloud into the Slovak national cartographic system.

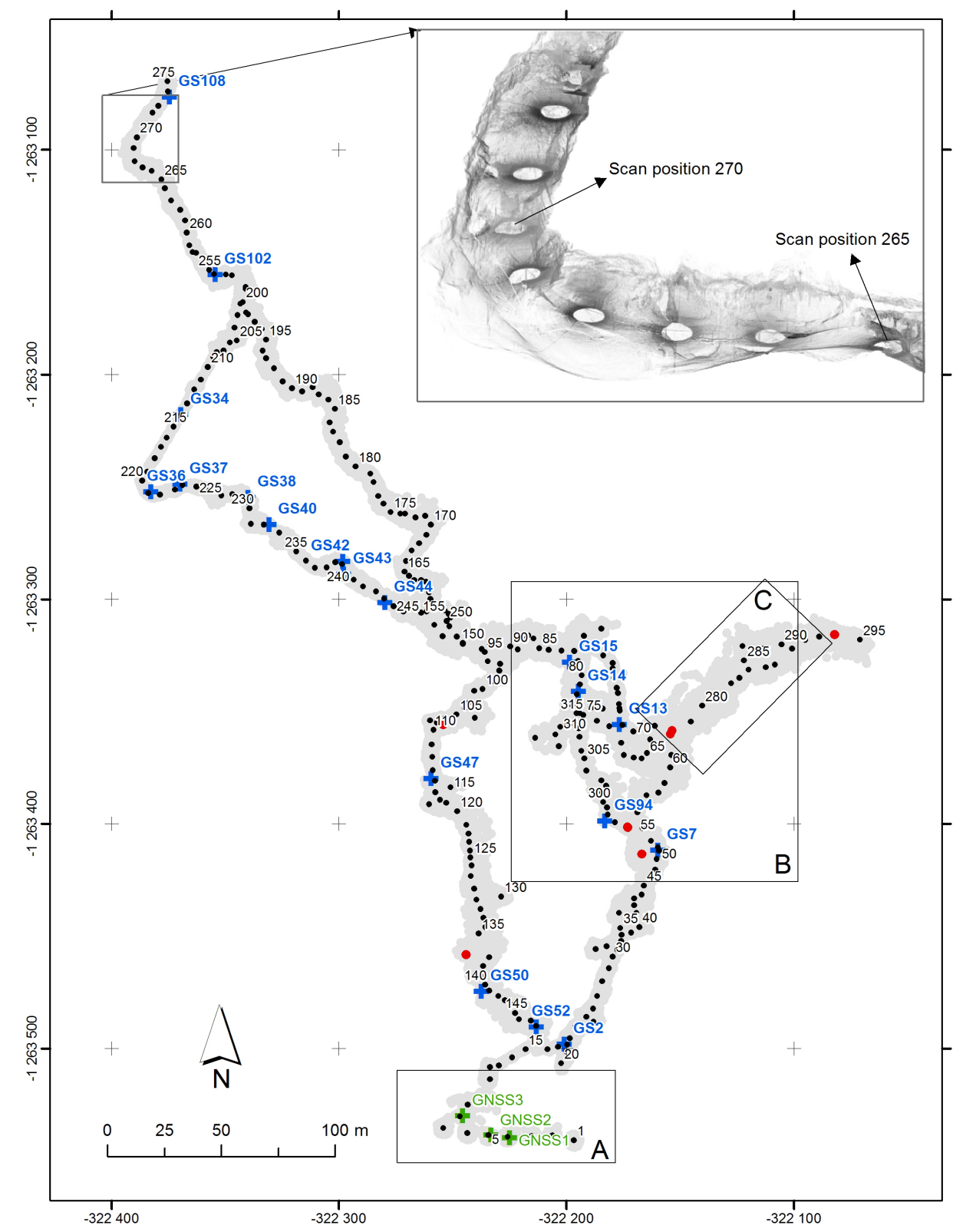

Fig. 3. Top view of the point cloud footprint overlain with numbered positions of the scanner for each scanned scene. Black dots denote positions at which scans of $1 / 5$ or $1 / 4$ resolution setting were acquired and red dots denote scans of 1/2 resolution setting. Green crosses represent points measured with RTK GNSS at the cave entrance and blue crosses represent points surveyed by Geological Survey (Novoveský, 1975) which were used to validate georeferencing and error propagation. The labelled rectangles locate: $(A)$ the extent of the scans acquired in the exterior of the cave, (B) the extent of the dome of Majkov dóm displayed in the old map in Fig. 2, (C) locates the detailed view in Fig. 5. The image in the upper right corner shows a magnified perspective view of the point cloud demonstrating a sequence of scanner positions manifested as circular footprints on the ground due to $300^{\circ}$ vertical scanning angle. The grid of ticks denotes coordinates in the national coordinate system (EPSG: 5514) measured in metres. 


\section{Visualization and 3-D cave surface model}

The final georeferenced point cloud is the ultimate result of scanning the cave, but more importantly, it can be regarded as a tool for further research. Viewing the points and simple measurements with them is the simplest yet very powerful approach to be taken for exploration of new knowledge contained in this unique dataset. We used the FARO SCENE and Bentley Pointools for handling the full point-cloud. To explore the relations with the digital terrain model of the above surface, the data were homogeneously decimated to 0.03 percent (3.27 million of points) for importing it into the ArcGIS (a software by ESRI). The Meshlab software (Cignoni \& Ranzuglia, 2014) was used to generate a 3-D cave surface model from the decimated point cloud. The data were exported from FARO Scene in the PTX format which preserves normal vectors to the points. Orientation of the normals is established with respect to the scanner position from which the range to the points was measured. By this means, normals do not need to be calculated in Meshlab and the surface model (a triangular mesh) can be directly reconstructed using several algorithms. We used the Poisson surface reconstruction algorithm (Kazhdan et al., 2006) with the octree depth of 13 and other parameters set to default. This method was also used by Silvestre et al. (2015). The model is stored in the PLY format and for interoperability with ArcGIS it was also exported in the DXF format (Fig. 4A). More aspects of 3-D modelling and geomorphometry of selected parts of the Domica Cave are addressed in Gallay et al. (2015). The 3-D cave surface model enabled volumetric calculations and basic analysis of the cave surface.

\section{RESULTS AND DISCUSSION}

The adopted methodology of TLS survey in Domica resulted in high-resolution and accurate $3-\mathrm{D}$ point representation of approximately $1,600 \mathrm{~m}$ of the cave passages. The survey job was done within 5 days (circa 45 working hours) and involved scanning from 327 separate locations (Fig. 3). The final point cloud contains over 11.9 billion $3-\mathrm{D}$ coordinates with intensity values of the backscattered laser energy (33 GB of data in the FLS native FARO format) representing the entire show cave and some corridors inaccessible to the public. Registration of individual scans into the final point cloud was based on 1,690 correspondences between targets and the total accuracy of registration reached $2.24 \mathrm{~mm}$ (RMSE). Other statistics are reported in Table 3. One loop in the network comprising scans from nr. 16 to nr. 149 (Fig. 3) was used to adjust the registration error in the loop. The error resulting from the processing of the loop was $0.32 \mathrm{~mm}$ after adjustment.

Geodetic transformation of the registered point cloud from its local system into the national grid system using the four reference points (GNSS 1-3 and GS108, Fig. 3) introduced the total error of $21 \mathrm{~mm}$. If only the three GNSS points at the cave entrance had been used the error of geodetic transformation would be lower $(10 \mathrm{~mm})$ but the total error at the point
GS108 in the most distant part of the scanned traverse from the cave entrance would increase to $5,907 \mathrm{~mm}$. Tacheometry from the older survey (Novoveský, 1975) combined with our TLS survey increased the global accuracy and reduced the propagation of errors due to successive registrations on spheres placed along the cave. The remaining set of 18 points surveyed in 1975 were used to calculate differences between their coordinates as extracted from the georeferenced final TLS point cloud and their national grid coordinates reported in Novoveský (1975). Total RMSE was 418 $\mathrm{mm}$ giving information on overall accuracy of locating the final point cloud in the national grid system. This error is mainly affected by (i) accuracy of locating the surveying nails in the TLS point cloud which was possible at the level of few millimetres and (ii) by accuracy of surveying in particular traverses from few millimetres to over a decimetre (See the section on collection of existing data).

The final point cloud is handled as a FARO SCENE project which can be loaded into the viewer version of the software (SCENE LT) and as a FARO SCENE Webshare Server off-line solution providing other colleagues with the means of visualizing the complete point cloud at the highest level of resolution, performing measurement of distances, or exporting selected parts of the cave into other formats. Reconstruction of a 3-D surface model in full resolution is possible only for several square metres of the cave surface. Generating 3-D cave surface models for larger parts is feasible after significant decimation of the original dataset.

Table 3. Summary statics of differences between corresponding targets used in the registration of point clouds acquired from individual scanner positions.

\begin{tabular}{|l|c|}
\hline \multicolumn{1}{|c|}{ Measured variable } & Value \\
\hline Scanner positions (count) & 327 \\
\hline Sum of matched targets (count) & 1,690 \\
\hline Minimum difference $(\mathrm{mm})$ & 0.07 \\
\hline Mean difference $(\mathrm{mm})$ & 1.98 \\
\hline Maximum difference $(\mathrm{mm})$ & 6.60 \\
\hline Standard deviation of differences $(\mathrm{mm})$ & 1.04 \\
\hline Root mean squared difference $(\mathrm{mm})$ & 2.24 \\
\hline
\end{tabular}

\section{Comparing the survey with other studies}

Application of TLS in caves is always a question of the time available for the survey, accessibility of the cave and its environmental conditions and the scanner's parameters. These aspects need to be contemplated when comparing our results with the studies presented in Table 1 and 2. First, we analyse specific trends which can be observed from the review. TLS have been successfully used for high-resolution 3-D mapping of caves in a number of studies since the first such applications of the technology seven years ago. Normally TLS surveyed caves have a comparatively easy access and are friendly for walking. This is usually the case of natural show caves which are open to the public (Gašinec et al., 2012; Berenguer-Sempere et al., 2014). Also caves affiliated to mines (Canevese et al., 2009; Canevese et al., 2011) are mostly easily accessible via mining shafts. The reason for selecting 
accessible caves is more likely in portability of the scanning device and related equipment which was available for particular studies at that time than the surveyor's comfort at work. In contrary, the studies of Buchroithner \& Gaisecker (2009) and Canevese et al. (2009) are examples of undertaking TLS under extreme environmental conditions. From this point of view, our mission presents a case of an easily accessible show cave. However, several narrow passages and spaces not accessible to the public were also scanned which would not be possible with bigger and heavier scanning devices. In comparison with the very fast mobile laser scanning presented by Zlot \& Bosse (2014), the low weight and portability of the scanner used in Domica did not compromise the accuracy of the final point cloud. We still achieved a total registration accuracy of only a $2.24 \mathrm{~mm}$. The result is very good considering such a large number of scans and length of the scanning traverse. This is especially associated with the method of thoughtful placing the spherical targets within each scene and registration based on manual approach to continually monitor errors of automatic recognition of the spheres between consecutive scans. Such high registration accuracy of TLS has been achieved only with the help of tacheometric surveying of several control points (e.g. Buchroithner \& Gaisecker, 2009; Gašinec et al., 2012; Bella et al., 2015) which requires use of additional equipment and more time for surveying.

\section{Analysing the 3-D cave surface model}

The generated 3-D cave surface model (Fig. 4A, B) enables calculation of the cave volume and other geometric variables in Table 4. Although the model does not represent the entire cave system, it provides realistic quantification of the 3-D geometry for the scanned area which was not available ever before. The parameters listed from the third to the ninth row of Table 4 are based on the definition stated in the manuals of the cave mapping software COMPASS (http://www. fountainware.com/compass/). The parameters were used to calculate volume density which is a rough estimate of the proportion of the cave volume to the rectangular block bounded by the $\mathrm{x}, \mathrm{y}$, and $\mathrm{z}$ extremities of the cave occupied by cave passage. The low value of $0.65 \%$ means that the cave occupies only a very small fraction of the surrounding rock environment (enclosed volume). It indicates a relatively young age of cave formation which has been mainly directed by modern hydrological conditions, or a short time in which the cave was crossed by the river before entrenchment made the active flow find another lower lying path, for example. It is known that many parts of the cave corridors are filled with gravels and silt (Droppa, 1972) and the volume of the cave is likely to be much bigger.

\section{Analysing the cave surface morphology}

One of the greatest benefits of the TLS technology over more traditional surveying methods are the highresolution data that can be interactively viewed and analysed at different scales. This enables extraction of new information on the Domica morphology and capture details of the cave interior.
Table 4. Geometric variables calculated from the 3-D cave surface model.

\begin{tabular}{|l|c|}
\hline Measured variable & Value \\
\hline Number of the mesh vertices (count) & $2,813,663$ \\
\hline Number of the mesh triangular faces (count) & $5,627,420$ \\
\hline Surface length, west to east $(\mathrm{m})$ & 354 \\
\hline Surface width, north to south $(\mathrm{m})$ & 416 \\
\hline Maximal vertical difference $(\mathrm{m})$ & 47.44 \\
\hline Surface area $\left(\mathrm{m}^{2}\right)$ & 33,990 \\
\hline Enclosed volume $\left(\mathrm{m}^{3}\right)$ & $7,068,672$ \\
\hline Volume of the 3-D cave surface model $\left(\mathrm{m}^{3}\right)$ & 46,148 \\
\hline Volume density $(\%)$ & 0.65 \\
\hline
\end{tabular}

The level of detail represented by the point cloud allows for the visualisation and measurement of small geomorphological features such as speleothems (Fig. 4C, 5) representing stalactites and even thin straws having only a few millimetres in diameter. Several morphological features are specific for the Domica Cave. These are represented by the largescale meandering ceiling channels, cascade lakes, or abundant speleothems as small-scale features of which cave shields are specific (Fig. 5). Hill \& Forti (1997, p. 98) describe the shield as an oval or circular

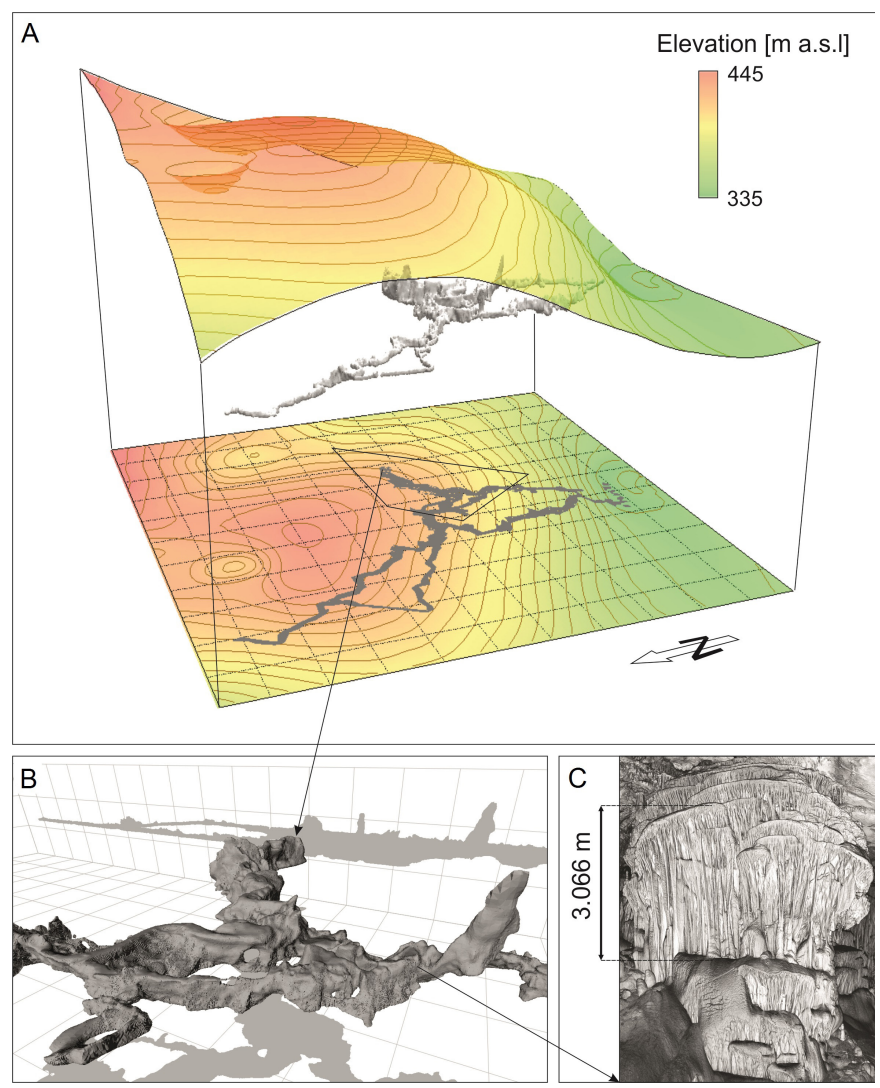

Fig. 4. (A) Perspective view of the simplified 3-D cave surface model representing the Domica Cave integrated with a digital terrain model in a geographic information system. The models are also projected on a horizontal plane. The interval of terrain altitude contours is $5 \mathrm{~m}$ and the cell size of the national grid is 50 by $50 \mathrm{~m}$. The cave model is based only on $0.03 \%$ of points acquired in by the TLS; (B) Closer perspective view of the cave surface model also projected on vertical $y z$-plane and horizontal $x y$-plane showing the medium-scale features with the grid of 20 by $20 \mathrm{~m}$ cell size; (C) Frontal view of the cave interior showing micro-scale features of the sinter columns known as the Samson's pillars (Samsonove stípy in Fig. 2) demonstrating the full resolution of the point cloud captured by the TLS. 
speleothem consisting of two spherical parallel plates or discs which are separated by a medial crack. Shield can form on a cave wall, ceiling and floors along joints from reprecipitated calcite located beneath joints and they are believed to be formed by the seepage of hydrostatic water along the joints or fractures in the bedrock. Increased flow of water can cause formation of dripstone on the bottom plate of a shield. Webb (1991) distinguishes cave shields formed on the cave floor as stegamites. In Czech and Slovak terminology Kunský (1950) described the same form as a spring dripstone formed by water leaking out from a crack in the cave floor, walls, or ceiling due to hydrostatic pressure (as a spring). Cílek (1999) and Bella (1999) provide more details on genesis and typology of the cave shields in Domica.

The fine details and accuracy of the mapping is shown within the selected area of the dome of Majkov dóm (Fig. 6). The dome is displayed from a 3-D perspective and coloured according to the altitude values. The traditional map of the cave would depict the cave footprint (Fig. 2) and, in this case, it would show the cave floor which often is the large area of the bottom part of the 3-D point cloud (Fig. 6A). The point cloud can be sliced to provide meaningful cross-sections as, for example, in horizontal (Fig. 6B) or vertical direction (Fig. 6C). However, the visualization clearly shows slanted walls and winding ceiling channels as solutional grooves formed by water mostly flowing over a surface of sediment that once nearly filled the cave (Neudorf et al., 2005, p. 103). Especially, the unreachable ceiling parts of the $20 \mathrm{~m}$ high dome can be precisely mapped only with laser scanning and the tacheometric surveying would be problematic. Figure 7 shows where the channel can be clearly distinguished and easily traced (Fig. 7A) in some parts but there are also passages where this important geomorphological feature is obscured by recent speleothems and it is too high to be reached safely (Fig. 7B, C). The ceiling channels in Domica were first studied by Roth (1938) who also discusses their formation by paragenesis. His findings are based on observation and they are presented in a descriptive manner while the new TLS technology enabled linking his work to detailed visualization and precise measurement of the channels. Figure 7 emphasizes the upper parts of the cave ceiling of a $2.5 \mathrm{~m}$ thin range of altitudes clearly showing the level of ceiling channel spanning from the west to the east indicated by blue dashed arrows. The adjacent branches of cave ceiling having north to south direction are genetically related to the channels and they must have originated in the same time as they formed in the same altitudinal range. In the next phases of cave formation, the river Styx accommodated to the new erosional base forming its channel $10 \mathrm{~m}$ below the ceiling channel level. The 3-D scatterplot displays only the points representing the extracted ceiling channel and projections of the points onto the xz-plane and yz-plane. The trend line of the point projections on the yz-plane provides evidence of the ceiling inclination towards east indicating the flow direction at the time when the ceiling was formed by an active river.

The possibility of integrating the 3-D dataset with other geospatial layers is very beneficial for studying the relationship of the cave system to the abovesurface. Figure 4 provides a striking view combining the TLS data and land surface digital elevation model showing the position of the cave within a larger 3-D landscape context.

\section{CONCLUSIONS}

Terrestrial laser scanning is now widely used as a mapping technology in many application areas. However, in cave mapping this technology faces many difficulties resulting from extreme space and environmental conditions that make its use in speleological research challenging. In this paper, we presented the methodological framework of adopting TLS to rapidly map a part of the Domica Cave system in Slovakia with the highest possible accuracy. The resulting point cloud was used to generate a digital 3-D model of the cave surface in order to visualise and analyse the morphological aspects indicating development of the cave system. The unprecedented accuracy of scans registration and resolution of mapping the cave surface resulted in capturing morphological details that could not be mapped by
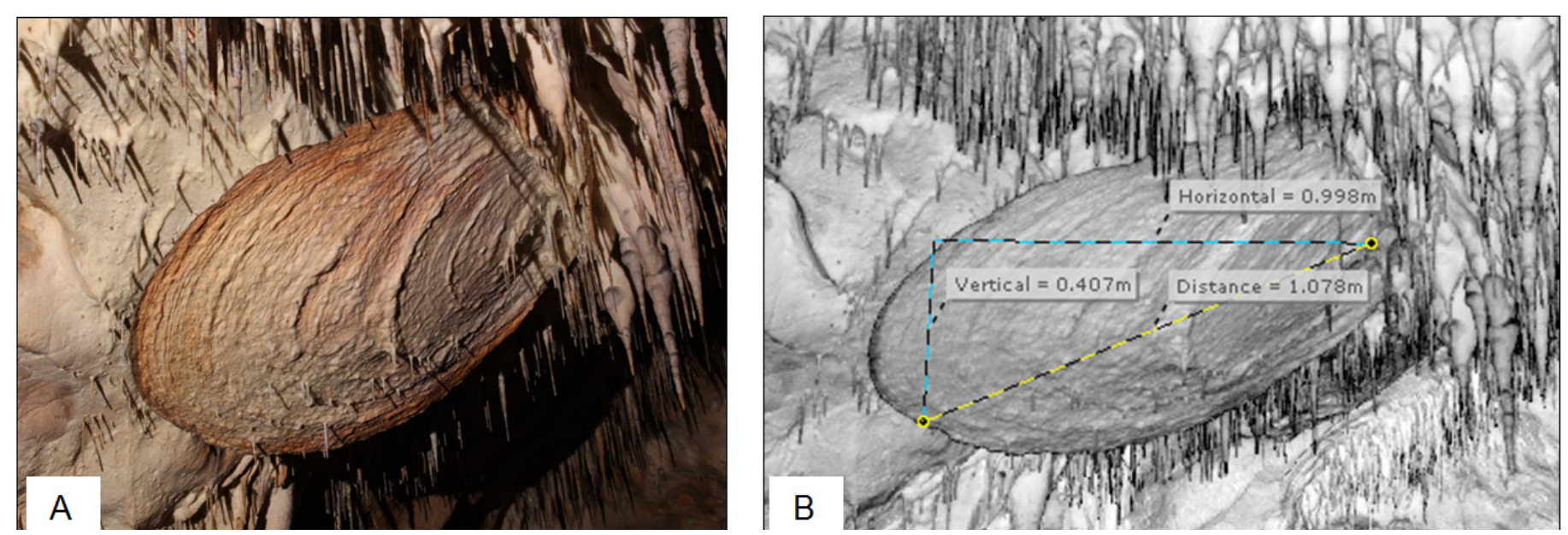

Fig. 5. Cave shield as a typical speleothem form in the Domica Cave photographed (A) and measured as a point cloud (B), which was selected from the scan position nr. 253 (see Fig. 3). 

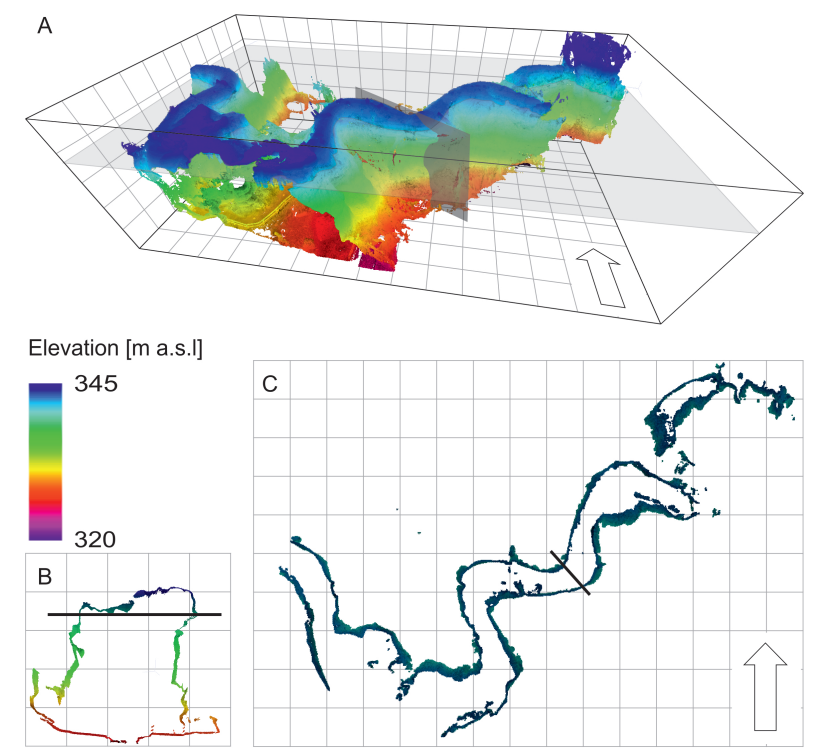

Fig. 6. Different approaches in visualization of the acquired laser scanning point cloud showing the dome of Majkov dóm as a 3-D perspective view $(A)$, vertical cross-sections $(B)$, and a horizontal profile at $338 \mathrm{~m}$ a.s.I (C) shown as grey cutting plane in A. The scale is given by the grid of 5 by $5 \mathrm{~m}$ cell size in all three directions. The dome is located in Fig. 3B.

traditional methods. Moreover, this study showed that the resulting point cloud can be cartographically transformed to the national cartographic projection and integrated with other data in a GIS to analyse wider context and processes forming the cave system. The 3-D cave surface model showed complex morphology of the cave including specific morphological forms, such as ceiling channels, indicating the speleogenetic processes.

The final point cloud contains more than 11.9 billion of points acquired from 327 scanning positions mapping over 1,600 $\mathrm{m}$ of the cave system. The acquired data set is, to our knowledge, the most detailed and most accurately measured dataset available for such a complex cave system. The most important factor in achieving the high accuracy of the registration process was in using spherical targets and their thoughtful placement during the laser scanning phase. This enabled us to achieve highly accurate alignment of individual scans and georeferencing the final point cloud into the national grid coordinate system with accuracy fairly acceptable for most speleological tasks. However, the accuracy of georeferencing and associated error propagation could be improved if simultaneous tacheometry and levelling had been performed. Modelling the 3-D cave surface in the full extent of the point cloud enables volumetric calculations, but it is feasible only with a significantly decimated point cloud. Original resolution can be used for much smaller parts of the cave.

We can conclude that TLS can be also used effectively for high-detailed mapping of large cave systems. This provides new possibilities for detailed research of cave morphology and processes forming the caves. However, this mapping method still faces many challenges. For example, future research activities should include development of new techniques and software tools for a faster processing of TLS data, visualisation and modelling enabling the researcher to interactively

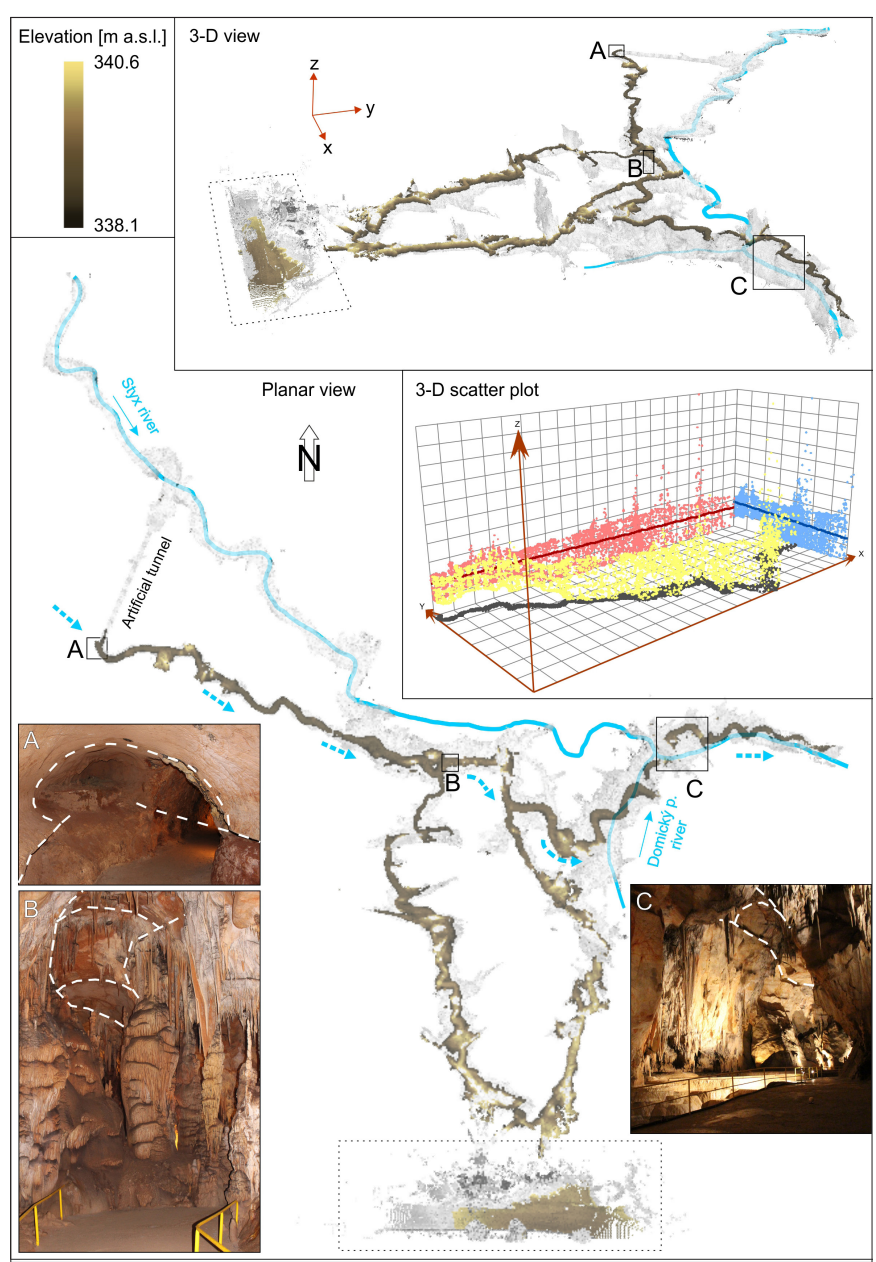

Fig. 7. Identification of the ceiling river as a large-scale morphologcial feature using the final point cloud and relation to other parts of the Domica Cave. The area outlined with a grey dotted line marks the visitors centre outside the cave. The channels are apparent in the planar view and perspective 3-D view (upper right) when displayed as a layer of points between 338 to $340.5 \mathrm{~m}$ above sea level. The points are coloured with yellow to brown scale depending on altitude. Current water streams are highlighted with solid blue line while the direction of the paleo channel of Styx is indicated with blue dashed arrows. The layer of points representing the ceiling channel can be statistically analysed in a GIS as a 3-D scatterplot which shows their projections with trend lines. The trend line of point projections (shown in red) in the vertical xz-plane (north to south direction) indicates the overal inclination of the channel towards the south. Selected views of the ceiling are displayed in the photographs $(A, B, C)$ where the channel is traced with a white dashed line.

inspect and analyse a 3-D cave surface model and simulate spatial processes. Also, the integration of TLS data and 3-D cave surface models into complex GIS systems with a full 3-D support would open up new research possibilities in analysing wider spatial interactions.

\section{ACKNOWLEDGEMENTS}

This work originated within the scientific research project: New methods of spatial modelling with laser scanning data and 3-D GIS nr. APVV-0176-12 funded by the Slovak Research and Development Agency. This research was also funded within the projects supported by the Slovak Research Grant Agency VEGA nr. 1/0473/14. We would also like to thank the officials of the Slovak Cave Administration for granting us permission to undertake this research and to the 
officials of the Slovak Museum of Nature Protection and Caving in Liptovský Mikuláš. We are grateful for the comments and suggestions of the three reviewers and editors who carefully read the manuscript and provided critical feedback on the content to improve its scientific quality.

\section{REFERENCES}

Addison A., 2011 - LIDAR at Mammoth Cave. Civil Engineering Surveyor, April 2011: 22-25.

Azmy S.N., Sah S.A.M., Shafie N.J., Ariffin A., Majid Z., Ismail M.N.A. \& Shamsir M.S., 2012 - Counting in the dark: Non-intrusive laser scanning for population counting and identifying roosting bats. Scientific Reports, 2 (524).

http://dx.doi.org/10.1038/srep00524

Bárta J., 1965 - Príspevok $k$ pravekému osidleniu jaskýn̆ Domickej sústavy (Contribution to the prehistoric settlement of the caves of the Domica system). Slovenský Kras, 5: 58-73 (in Slovak, English summary)

Bella P., 1999 - Typy sintrových štitov a bubnov v jaskyni Domica (The types of speleothem shields and drums in the Domica Cave), Aragonit, 4: 3-6. (in Slovak)

Bella P., 2001 - Geomorfologické pomery okolia jaskyne Domica (Geomorphological settings of the Domica Cave). Aragonit, 3: 5-11. (in Slovak)

Bella P. \& Holúbek P., 2001 - Meandrová chodba $v$ jaskyni Domica. Aragonit, 6: 11-15. (in Slovak)

Bella P., Braucher R., Holec J. \& Veselský M., 2014 Burial age of cemented quartz gravel in the upper level of the Domica Cave, Slovakia. In: Book of abstracts, 8th Scientific Conference of the Association of Slovak Geomorphologists at the Slovak Academy of Sciences, Snina: $10-11$

Bella P., Littva J., Pukanská K, Gašinec J. \& Bartoš K., 2015 - Use of terrestrial laser scanning for the investigation of structural geological discontinuities and morphology of caves: on the example of the Dúpnica Cave, Západné Tatry Mts., Slovakia. Acta Geologica Slovaca, 7 (2): Article in press.

Berenguer-Sempere F., Gómez-Lende M., Seranno E. \& de Sanjosé-Blasco J.J., 2014 - Orthothermographies and $3 D$ modeling as potential tools in ice caves studies: the Peña Castil Ice Cave (Picos de Europa, Northern Spain). International Journal of Speleology, 43: 35-43. http://dx.doi.org/10.5038/1827-806X.43.1.4

Beres M., Luetscher M. \& Olivier R., 2001 - Integration of ground-penetrating radar and microgravimetric methods to map shallow caves. Journal of Applied Geophysics, 46 (4): 249-262. http://dx.doi.org/10.1016/S0926-9851(01)00042-8

Birch S., 2008 - Laser Scanning at High Pasture Cave. http://www.high-pasture-cave.org/index.php/news/ comments/168/ High Pasture Cave News [accessed: June 5, 2015].

Bosse M., Zlot R. \& Flick P. 2012 - Zebedee: Design of a spring-mounted $3 D$ range sensor with application to mobile mapping. IEEE Transactions on Robotics, 28 (5): 1104-1119.

http://dx.doi.org/10.1109/TRO.2012.2200990

Bremer M. \& Sass O., 2012 - Combining airborne and terrestrial laser scanning for quantifying erosion and deposition by a debris flow event. Geomorphology, $138 \quad$ (1): 49-60. http://dx.doi.org/10.1016/j.geomorph.2011.08.024

Buchroithner M.F., 2015 - Mountaincartography 'down under' - Speleological 3D Mapping. Wiener Schriften zur Geographie und Kartographie, Wien, 21: 93-204.
Buchroithner M.F. \& Gaisecker T., 2009 - Terrestrial laser scanning for the visualization of a complex dome in an extreme Alpine cave system. Photogrammetrie Fernerkundung Geoinformation, 4: 329-339. http://dx.doi.org/10.1127/1432-8364/2009/0025

Buchroithner M.F., Milius J. \& Petters C., 2011 - 3D Surveying and Visualization of the Biggest Ice Cave on Earth. Proceedings of $25^{\text {th }}$ International Cartographic Conference, 8-11 July 2011, Paris.

Buckley S.J., Kurz T.H., Howell J.A. \& Schneider D., 2013 - Terrestrial lidar and hyperspectral data fusion products for geological outcrop analysis. Computers \& Geosciences, 54 (4): 249-258. http://dx.doi.org/10.1016/j.cageo.2013.01.018

Budaj M. \& Mudrák S., 2008 - Therion - Digital Cave Maps. In: Spelunca Mémoires (French Federation of Speleology), 33: 138-141.

Burens A., Grussenmeyer P., Carozza L., Leveque F., Guillemin S. \& Mathe V., 2014 - Benefits of an accurate $3 D$ documentation in understanding the status of the Bronze Age heritage cave "Les Fraux" (France). International Journal of Heritage in the Digital Era, 3 (1): 179-196.

http://dx.doi.org/10.1260/2047-4970.3.1.179

CAVERBOB - World's Longest Caves. http://www. caverbob.com/wlong.htm Bob Gulden [accessed: July 14, 2015]

Canevese E.P., Tedeschi R. \& Forti P., 2009 - The caves of Naica: laser scanning in extreme underground environments. The American Surveyor, 6 (2): 8-19.

Canevese E.P., Forti P, Naseddu A., Ottelli L. \& Tedeschi, R., 2011 - Laser scanning technology for the hypogean survey: the case of Santa Barbara karst system (Sardinia, Italy). Acta Carsologica, 40 (1): 65-77.

Chamberlain A.T., Sellers W., Proctor C. \& Coard R., 2000 - Cave detection in limestone using ground penetrating radar. Journal of Archaeological Science, 27 (10): 957964. http://dx.doi.org/10.1006/jasc.1999.0525

Cignoni P. \& Ranzuglia G., 2014 - MeshLab, Visual Computing Lab - ISTI - CNR http://meshlab. sourceforge.net/ [accessed: June 5, 2015].

Cílek, V., 1999 - Problém geneze sintrových štitů z jeskynĕ Domica (The problem of genesis of speleothem shields from the Domica Cave). Aragonit, 4: 7-9. (in Czech)

Cosso T., Ferrando I. \& Orlando A., 2014 - Surveying and mappingacaveusing 3 dlaserscanner:Theopenchallenge with free and open source software. In: The International Archives of the Photogrammetry, Remote Sensing and Spatial Information Sciences, XL-5: ISPRS Technical Commission V Symposium, Riva del Garda: 181-186. http://dx.doi.org/10.5194/isprsarchivesXL-5-181-2014

Droppa A., 1972 - Príspevok k vývoju jaskyne Domica (Contribution to the development of the Domica Cave). Československý kras, 22: 65-72. (in Slovak).

Gaál L. \& Vlček L., 2011 - Tectonics of the Domica cave (Slovak Karst). Aragonit, 16 (1-2): 3-11. (in Slovak).

Gaalova B., Donauerova A., Seman M. \& Bujdakova H. 2014. Identification and $\beta$-lactam resistance in aquatic isolates of Enterobacter cloacae and their status in microbiota of Domica Cave in Slovak Karst (Slovakia). International Journal of Speleology, 43: 69-77. http://dx.doi.org/10.5038/1827-806X.43.1.7 Gallay M., Kaňuk J., Hofierka J., Hochmuth Z. \& Meneely J., 2015 - Mapping and geomorphometric analysis of 3-D cave surfaces: a case study of the Domica Cave, Slovakia. In: Zwoliński Z., Jasiewicz J., Mitasova H. \& Hengl T. (Eds.), Geomorphometry 2105 Conference Proceedings, 22-26 June 2015, Poznań: 69-73. http://geomorphometry.org/2015 
Ganter J.H., 2000 - A guide to cave mapping. (2 $2^{\text {nd }}$ ed.). National Speleological Society, 28 p.

Gašinec J., Gašincová S., Černota P. \& Staňková H., 2012 - Uses of terrestrial laser scanning in monitoring of ground ice within Dobšinská Ice Cave. Journal of the Polish Mineral Engineering Society, 30 (2): 31-42.

Gede M., Petters C., Nagy G., Nagy A., Mészáros J., Kovács B. \& Egri C., 2013 - Laser scanning survey in the Pálvölgy Cave, Budapest. In: Buchroithner M.F. (Ed.), Proceedings of the $26^{\text {th }}$ International Cartographic Conference. International Cartographic Association, Dresden: 905 p.

Geological Survey, 1975 - Domica mapa 1:500, Geologický prieskum Spišská Nová Ves, n.p.

Gonzalez-Aguilera D., Muoz A.L., Lahoz J.G., Herrero J.S., Corchon M.S. \& Garcia E., 2009 - Recording and modeling Paleolithic caves through laser scanning. In: International Conference on Advanced Geographic Information Systems \& Web Services, Cancun: 19-26. http:/ / dx.doi.org/10.1109/GEOWS.2009.7

Gradziński M., Hercman H., Nowak M. \& Bella P., 2007 Age of black coloured laminae within speleothems from Domica Cave and its significance for dating of prehistoric human settlement. Geochronometria, 28 (1): 39-45. http://dx.doi.org/10.2478/v10003-007-0029-7

Grussenmeyer P., Alby E., Landes T., Koehl M., Guillemin S., Hullo J.-F., Assali P. \& Smigiel E., 2012 - Recording approach of heritage sites based on merging point clouds from high resolution photogrammetry and terrestrial laser scanning. In Shortis M. \& Mills J. (Eds.) $22^{\text {nd }}$ ISPRS Congress, International Archives of the Photogrammetry, Remote Sensing and Spatial Information Sciences, XXXIXB5, Melbourne, Australia: 553-558.

http://dx.doi.org/10.5194/isprsarchivesXXXIX-B5-553-2012

Heeb B., 2009 - An all-in-one electronic cave surveying device. Cave Radio \& Electronics Group Journal, 72: 8-10.

Hill C.A. \& Forti, P., 1997 - Cave minerals of the world ( $2^{\text {nd }}$ ed.). National Speleological Society, Huntsville, 463 p.

Hoffmeister D., Zellmann S., Kindermann K., Pastoors A., Lang U., Bubenzer O., Weniger G.-C. \& Bareth G., 2014 - Geoarchaeological site documentation and analysis of $3 D$ data derived by terrestrial laser scanning. ISPRS Annals of the Photogrammetry, Remote Sensing and Spatial Information Sciences, II-5: 173-179.

Höfle B. \& Rutzinger M., 2011 - Topographic airborne LiDAR in geomorphology: A technological perspective. Zeitschrift für Geomorphologie, 55 (2): 1-29.

http://dx.doi.org/10.1127/0372-8854/2011/0055S2-0043

Hochmuth Z., 1995 - Mapovanie jaskýn̆ (Cave mapping). Slovenská speleologická spoločnost', Liptovský Mikuláš, Slovakia, 80 p. (in Slovak)

Kasprzak M., Sobczyk A., Kostka S. \& Haczek A., 2015 Surface geophysical surveys and LiDAR DTM analysis combined with underground cave mapping - an efficient tool for karst system exploration: Jaskinia Niedzwiedzia case study (Sudety, Poland). In: Zwoliński Z., Jasiewicz J., Mitasova H. \& Hengl T. (Eds.), Geomorphometry 2105 Conference Proceedings, Poznań: 75-78. http:/ / geomorphometry.org/2015

Kazhdan M. M., Bolitho M. \& Hoppe H., 2006 - Poisson surface reconstruction." In: Sheffer, A. \& Polthier, K. (Eds.), Symposium on Geometry Processing, ser. ACM International Conference Proceeding Series, Eurographics Association, 2006, 256: 61-70.

Kessler H., 1938 - Az Aggteleki barlangrendszer hidrográfiája. Földrajzi Közlemények, Budapest, 66 (1-3): 1-30. (in Hungarian)
Kováč, L. \& Rusek, J., 2012 - Redescription of two troglobiotic species of the genus Pseudosinella Schäffer, 1897 (Collembola, Entomobryidae) from the Western Carpathians. Zootaxa, 3341: 32-45.

Kunský J., 1950 - Kras a jeskyně (Karst and caves). Československá společnost zeměpisná, Přirodovědecké nakladatelství, Prague, 200 p. (in Czech)

Lemmens M., 2008 - Terrestrial laser scanners. GIM International, Product overview, 62-67.

Lerma J.L., Navarro S., Cabrelles M. \& Villaverde V., 2009 - Terrestrial laser scanning and close range photogrammetry for $3 D$ archaeological documentation: the Upper Palaeolithic Cave of Parpallo as a case study. Journal of Archaeological Science, 37 (3): 499-507. http://dx.doi.org/10.1016/j.jas.2009.10.011

Lichardus J., 1968 - Jaskyña Domica: najvýznačnejšie sidlisko l'udu bukovohorskej kultúry (Domica Cave: the Most Important Site of the Bükk Culture people). Vydavatel'stvo Slovenskej akadémie vied, Bratislava, 120 p. (in Slovak)

Lichti D. \& Skaloud J., 2009 - Registration and calibration. In: Vosselman G. \& Maas H.-G. (Eds.), Airborne and terrestrial laser scanning. Whittles Publishing, Dunbeath, p. 83-129.

Lindgren S. \& Galeazzi F., 2013 - 3D laser scanning in cave environment: The case of las cuevas, Belize acquisition of the cave system and excavation area. Digital Heritage International Congress (DigitalHeritage), 1: 219-222. http://dx.doi.org/10.1109/DigitalHeritage. $\underline{2013.6743737}$

Mallet C. \& Bretar F., 2009 - Full-waveform topographic lidar: State-of-the-art. ISPRS Journal of Photogrammetry and Remote Sensing, 64 (1): 1-16. http://dx.doi.org/10.1016/j.isprsjprs.2008.09.007

Marsico A., Infante M., Iurilli V. \& Capolongo D., 2015 - Terrestrial laser scanning for 3D cave reconstruction: Support for geomorphological analyses and geoheritage enjoyment and use. In: Andreo B., Carrasco F., Durán J.J., Jiménez P. \& LaMoreaux J. (Eds.), Hydrogeological and environmental investigations in karst systems. Environmental Earth Sciences, 1: 543-550.

McFarlane D.A., Buchroithner M., Lundberg J., Petters C., Roberts W. \& Van Rentergen G., 2013 - Integrated three-dimensional laser scanning and autonomous drone surface- photogrammetry at Gomantong caves, Sabah, Malaysia. In: Filippi M. \& Bosák P. (Eds.), 16 ${ }^{\text {th }}$ International Congress of Speleology. Brno, Czech Republic, 2: 317-319.

McFarlane D.A., Roberts W., Buchroithner M., Van Rentergem G., Lundberg J. \& Hautz S., 2015-Terrestrial LiDAR-based automated counting of swiftlet nests in the caves of Gomantong, Sabah, Borneo. International Journal of Speleology, 44 (2): 191-195. http://dx.doi.org/10.5038/1827-806X.44.2.8

Mihailović D.T., Krmar M., Mimić G., Nikolić-Đorić E., Smetanová I., Holý K., Zelinka J. \& Omelka J., 2015 - A complexity analysis of 222Rn concentration variation: A case study for Domica cave, Slovakia for the period June 2010-June 2011. Radiation Physics and Chemistry, 106: 88-94.

http://dx.doi.org/10.1016/j.radphyschem.2014.06.016

Milius J. \& Petters C., 2012 - Eisriesenwelt - From Laser Scanning to Photo-Realistic 3D Model of the Biggest Ice Cave on Earth. In: Jekel T., Car A., Strobl J. \& Griesebner G. (Eds.), GI-Forum 2012: Geovisualization, Society and Learning. Salzburg: 513-523.

National Geographic, 2014 - Amazing 3-D tour of a Chinese supercave http://video.nationalgeographic. com/video/magazine/ngm-china-caves-3d National Geographic [accessed: June 5, 2015]. 
Neuendorf K.K.E., Mehl J.P. \& Jackson J.A., 2005 Glossary of Geology. American Geological Institute, Springer Science \& Business Media, 779 p.

Nováková A., 2009 - Microscopic fungi isolated from the Domica Cave system (Slovak Karst National Park, Slovakia). A review. International Journal of Speleology, 38 (1): 71-82.

http://dx.doi.org/10.5038/1827-806X.38.1.8

Novoveský 1975 - Technická správa, Domica 111-I-13. Geologický prieskum, n.p., Geologická služba podniku, geologická oblast' Rožñava (Technical report), Slovak Museum of Nature Protection and Caving, folder of scans SK_1219_32427_0023_00050. (in Slovak)

Paloncy E., 1932 - Jak sme měr̆ili v Domici (How we surveyed Domica). Krásy Slovenska, 11 (2-3): 48-53. (in Czech)

Pánek T., Margielewski W., Tábořík P., Urban J., Hradecký J. \& Szura C., 2010 - Gravitationally induced caves and other discontinuities detected by $2 D$ electrical resistivity tomography: Case studies from the Polish Flysch Carpathians. Geomorphology, 123 (1-2): 165-180. http://dx.doi.org/10.1016/j.geomorph.2010.07.008

Papáč V., Hudec I., Kováč L., Lúptáčik P. \& Mock A., 2014 - Bezstavovce jaskyne Domica (Invertebrates of Domica). In: Gaál L. \& Gruber P. (Eds.), Jaskynný systém Domica-Baradla. Jaskyña, ktorá nás spája. Jósvafő, Hungary: Aggteleki Nemzeti Park Igazgatóság, 267-279. (in Slovak and in Hungarian)

Patias P., Grussenmeyer P. \& Hanke K., 2008-Applications in Cultural Heritage Documentation. In: Li Z., Chen J. \& Baltsavias E. (Eds.), Advances in Photogrammetry, Remote Sensing and Spatial Information Sciences. ISPRS Congress Book, ISPRS Book Series, London: Taylor \& Francis Group, 7: 363-383.

Remondino F., Spera M.G., Nocerino E., Menna F. \& Nex F., 2014 - State of the art in high density image matching. The Photogrammetric Record, 29 (146): 144-166.

http://dx.doi.org/10.1111/phor.12063

Roncat A., Dublyansky Y., Spotl, C. \& Dorninger P., 2011 - Full-3D surveying of caves: A case study of Marchenhohle (Austria). In: Marschallinger R. \& Zobl F. (Eds.), Mathematical Geosciences at the Crossroads of Theory and Practice, Proceedings of the IAMG2011 conference, Salzburg: 1393-1403.

http://dx.doi.org/10.5242/iamg.2011.0000

Roth Z. 1937 - Vývoj jeskynnè Domice (Evolution of the Domica Cave). Časopis učené společnosti Šafařikovy v Bratislavě, 11: 129-163. (in Czech)
Rüther H., Chazan M., Schroeder R., Neeser R., Held C., Walker S.J., Matmon A. \& Kolska Horwitz L., 2009 Laser scanning for conservation and research of African cultural heritage sites: the case study of Wonderwerk Cave, South Africa, Journal of Archaeological Science, 36 (9): 1847-1856.

http://dx.doi.org/10.1016/j.jas.2009.04.012

Schön S., 2007 - Mit dem Laser im Labyrinth. http:/ / www. riegl.com/uploads/tx_pxpriegldownloads/Dachstein-

Reportage Saechsische Zeitung 2303 2007.pdf.

Sächsische Zeitung, March 24/25 2007, M2. (in German) [accessed: June 8, 2015].

Silvestre I., Rodrigues J. I., Figueiredo M. J. G. \& VeigaPires C., 2013 - Cave chamber data modeling and 3D web visualization. In: Banissi E., Azzag H., Bannatyne M.W.McK., Bertschi S., Bouali F., Burkhard R., Counsell J., Cuzzocrea A., Eppler M.J., Hammer B., Lebbah M., Marchese F.T., Sarfraz M., Ursyn A., Venturini G. \& Wyeld T.G. (Eds.), $17^{\text {th }}$ International Conference on Information Visualisation (IV), London: 468-473. http://dx.doi.org/10.1109/IV.2013.103

Silvestre I., Rodrigues J. I., Figueiredo M. \& Veiga-Pires C., 2015 - High-resolution digital 3D models of Algar de Penico Chamber: limitations, challenges, and potential. International Journal of Speleology, 44 (1): 25-35. http://dx.doi.org/10.5038/1827-806X.44.1.3

Svitavská-Svobodová H., Andreas M., Krištůfek V., Beneš J. \& Novák J. - The thousand-year history of the Slovak Karst inferred from pollen in bat guano inside the Domica Cave (Slovakia). Folia Geobotanica. 50 (1): 49-61. http://dx.doi.org/10.1007/s12224-015-9205-0

The Courier, 2004 - 3D laser scanning of the Wemyss Caves. - http://www.stonepages.com/news/archives/000757. html [accessed: June 5, 2015].

YouTube, 2013 - Gomantong Cave 3D model. https://www. youtube.com/watch?v=0fYUOZ3dnM0 Dan McFarlane [accessed: June 5, 2015].

Vosselman G. \& Maas H.G., (Eds.), 2010 - Airborne and terrestrial laser scanning. Whittles Publishing, Dunbeath, $318 \mathrm{p}$.

Webb R., 1991 - Stegamites - A form of cave shield? In: Proceedings of the $18^{\text {th }}$ Biennial Conference of the Australian Speleological Federation, Margaret River http://www.wasg.org.au/steg.html [accessed: July 14, 2015].

Zlot R. \& Bosse M., 2014 - Three-dimensional mobile mapping of caves. Journal of Cave and Karst Studies, 76 (3): 191-206.

http://dx.doi.org/10.4311/2012EX0287 